\title{
Property Tax and Quality of Life in the Czech Municipalities: Does the Policy of Raising Local Coefficient Imply Potential or Risk for Development?
}

\section{Pavel Zdražil, Bohuslav Pernica ${ }^{1}$}

\begin{abstract}
Since the 1990s, the Czech intergovernmental fiscal relations have been undergoing a transformation. One of the measurements strengthening the autonomy of local authorities was the introduction of the instrument of the local coefficient in 2009 which provided the municipalities with the possibility to raise real estate tax in order to maximize their revenues. The aim of this article is to statistically analyse the impact of this instrument on the quality of life in a sample of Czech municipalities which have changed the local coefficient from 1 up to 5. The empirical analysis consists of two parts - a non-parametrical correlation analysis and paired difference testing. It is carried out in context of population ageing versus population growth, and the availability of basic public services (education, health care, communication, public safety). The analysis proves that there are great differences between the municipalities that have increased the real estate taxes and municipalities that have not. In the second case, the municipalities are more threatened by population ageing as they face the growth of population while the number of working age citizens is declining together with the provision of public services. Meanwhile, the municipalities that have increased the coefficient of real estate taxes have experienced increase in both population and working age population sizes. Such municipalities do not face the problem of shrinking of public services. Also, the policy of raising local coefficient implies a potential for ongoing development of districts.
\end{abstract}

Key words: local coefficient, local government, municipality, quality of live, property $\operatorname{tax}$

JEL Classification: H71, H75, O18, O23

Received: 12 September 2017 / Accepted: 13 March 2018/Sent for Publication: 4 June 2018

\footnotetext{
${ }^{1}$ University of Pardubice, Faculty of Economics and Administration, Studentská 95, 532 10, Pardubice, Czech Republic. E-mail: pavel.zdrazil@upce.cz, bohuslav.pernica@upce.cz.
}

(c) 2018 by the authors; licensee Review of Economic Perspectives / Národohospodářský obzor, Masaryk University, Faculty of Economics and Administration, Brno, Czech Republic. This article is an open access article distributed under the terms and conditions of the Creative Commons Attribution 3.0 license, Attribution - Non Commercial - No Derivatives. 


\section{Introduction}

As a consequence of the financial crisis of 2007-2008, the central government in the Czech Republic strengthened the position of local authorities in fiscal federalism (Smith, Bryson and Cornia, 2011) in order to lower rising fiscal stress (Scidmore and Scorcone, 2011) in more than 6000 municipalities. In fact, these municipalities are dependent on revenues from the central Czech government accountable for tax collections. Since 1 January 2009, any local government has acquired the power to raise the property tax levied on real estate located in its district (Bečica 2014). Therefore, any local authority is entitled to setting up of a coefficient used for a local tax property calculation. This can influence fiscal revenue from the property tax without any obligation to spend extra money on a specific area of its responsibility. Nonetheless, such an increase of tax might make any residence in the municipality more expensive without getting any payoff in the form of improved quality of living conditions (Schneider, 1987). On the other hand, local authorities can use the extra revenues to mitigate the negative results of current patterns of local and regional development. In particular, urban sprawl, suburbanisation processes and shifting tax bases have fostered concerns about the geography of public services provision, i.e. how the public services can be founded and supported in the inner and outer city areas (Pike, Ródriguéz-Pose and Tomaney, 2006).

With all of the above in mind, the aim of this paper is to examine whether the policy of forceful raising of the property tax by the institute of local coefficients introduced in the Czech Republic in 2009 impacts the quality of life in municipalities which decided to raise this coefficient from 1 to 5 . There is no legal or moral obligation for the local governments in the Czech Republic to justify such a decision in public; any setting of the local coefficient is the issue of mayoral quality (Avellaneda 2009) rather than ideology (Blom-Hansen, Monkerud and Sorensen, 2006) Therefore, we assume that the collective decision of raising the local coefficient made by local authorities is driven by rationality of individual and collective well-being. Hence, any higher degree of taxation at the local level of government should be compensated with an adequate provision of public service provided or supported by municipalities such as schools, public libraries, access to health care, transportation and communication infrastructure, public safety, etc. In other words, we seek to determine whether the instruments of local coefficients imply a potential risk for ongoing local development.

\section{Review of literature}

From many points of view, the property tax levied on real estate, such as land and immovable man-made objects (buildings), i.e. real estate tax, is usually considered to be a perfect tax. Firstly, the object of the tax is tangible and bulky. Secondly, it is usually firmly tight to Earth. And finally, it is extremely complicated to conceal it from tax collectors so as to evade real estate tax (Alm, 2013). On the other hand, as an instrument of the public policy determining behaviour of public policy actors, such as residents, local governments and firms, the real estate tax might be considered to be the bone of contention.

Although the primary purpose of real estate tax is to get revenue needed for central, regional and local government activities at the lowest, implemented into fiscal system in a particular national state, it still poses many both theoretical and practical questions. 
For instance, with regard to the well-known impact of the Great Depression on the U.S. cities, Lutz, Molloy and Shan (2011) scrutinized how the property tax affected house prices in the U.S. during the financial crisis of 2007-2008. Blom-Hansen, Monkerud and Sorensen (2006) attempted to discover if the real estate tax rate in Norway and Denmark, as revenue of local budgets, was determined by the ideology of left- and right-wing parties. Due to the fact that local governments in Norway and Denmark, two well-known welfare states, are based on requirements of municipalities and their citizens, they did not find any substantial correlation between political orientation and the grade of the tax rate.

Schneider (1987) in his study dealt with the question of whether there were some differences among metropolitan, urban, sub-urban and rural districts in the U.S. regarding the ability of real estate property tax to be the revenue determining the wealth of a city. More specifically, the property tax issue is a frequent subject of research in the U.S., e.g. Fisher and Fairbanks (1967), as the property tax is a substantial source of income for municipalities (Alm, 2013). They are entrusted by the federal government with the provision of essential public services to their citizens, such as schooling, e.g. Chernick, Langley and Reschovsky (2011); hence the interrelationship between taxation by real estate tax and the quality of live supported by revenue from property tax. In addition, the property tax installed into prices determines the competition of Small and Medium Enterprises as well as the quality of schooling (Stevens and Mason, 1996); and also, thanks to the power to set the real estate tax rate, municipalities can compete with one another in order to either allure investors in their administration districts or to attract new citizens, like families seeking good education for their children (Crowley and Sobel 2011).

Smith, Bryson and Cornia (2011) analysed intergovernmental fiscal relations in the Czech Republic focusing on the level of fiscal decentralization. They chose the Czech Republic as the subject for their research as it is "a country engaged in an extended public sector transition from the central planning era" (Smith, Bryson and Cornia, 2011: 99). They further state: "But old habits die hard and the high degree of centralism of that period was deeply ingrained. Consequently, we continue to find in our encounters with the Czech Republic some of the characteristics of a substantially centralized fiscal system - with transfers from the center representing a large share of the total revenues of local budgets and at the local level, low local fiscal effort and very meager ownsource revenue generation." (ibid) As a measure supporting the fiscal decentralization might be seen the delegation of authority to set a part of the real estate tax rate from the central government to the local authorities. That might be considered as an essential move to support the relationship between taxpayers living in municipalities and local authorities taking care of their living standards with the provision of essential public services, such as schooling, streetlight, fire service, public library, tap water, post office, places to buy groceries, etc.

However, studies dealing with the impact of the above-mentioned innovation on the local quality of life are few. Researchers like Bečica (2014), Sedmihradská (2013) or Sedmihradská and Bakoš $(2015 ; 2016)$ scrutinize the aspects of the introduction of the local coefficient analysed in some of the studies mentioned above rather than evaluate the policy of raising of the local coefficient linked to the accessibility and quality of public services provided and funded by municipalities which have raised the real estate 
tax rate by changing the local coefficient from 1 to $2,3,4$ or 5 . In particular, Sedmihradská and Bakoš (2015) have published a list of Czech municipalities that have raised the local coefficient to deal with the phenomenon of tax mimicking (Sedmihradská and Bakoš, 2016). A good subject for further research could then revolve around the innovation introduced to the Czech fiscal system in 2009.

\section{Methods}

To fulfil the aim, we have conducted the analysis using the following assumptions and methods. The objective was to examine whether the local coefficients of real estate taxes, i.e. the part that is decided by a local (municipal) government, impacts the quality of life in the individual municipalities. Our sample consists of municipalities of the Czech Republic (as of 2011, i. e. 6,252 municipalities in total), covering the period 2011-2016. The period could seem short but the choice was based on both the unavailability of data on the quality of life and the fact that the method of determining the value of local coefficients of real estate taxes is quite a new established by the Act no. 261/2007 (in force since 2008), which amended the Act no. 338/1992. Its deployment has been slow and not every municipality has decided to apply this instrument (i.e. the coefficient remains at the value of 1 ).

Regarding the bottom units of regional hierarchy, the number of quality of life indicators is limited. Therefore, we only examine changes in population size and structure, and the presence of basic public services. In particular, we follow the traditional indicators like the existence of medical services and educational facilities (Phillips, 2006; Rogersonn et al., 1996; Korovchenko, 2016), as well as security services (Qizilbash, 1998:67) where the existence of a fire brigade is examined. These are some of the major indicators of several concepts of quality of life measurement, e.g. the theory of human need (Doyal and Gough, 1991), and they also correspond with the EU policy objectives, i.e. the improvement of living conditions and quality of life (Noll, 2002). Moreover, as an interesting indicator we also employ provision of post offices, an important public service threatened by the global shift to e-communication. The data on population, provision of medical service, educational facilities and post offices have been acquired from the Czech Statistical Office database (CZSO, 2017). The values of real estate taxes represent the local coefficients set by local governments. These data have been sourced from Sedmihradská and Bakoš (2017). Finally, the data on provision of a fire brigade have been obtained from the internal database of Fire Rescue Service of the Czech Republic (FRSCR, 2017).

We examine the issue both statistically and dynamically in order to compare any development patterns between the municipalities that have increased the local coefficient of real estate taxes and those that have not done so yet. Such a comparison will allow us to estimate whether the increased amount of local taxes might improve the quality of life in individual municipalities. First, we apply the correlation analysis to find whether there are any connections between the quality of life indicators and the level of local coefficients of real estate taxes. In other words, we seek to learn whether municipalities that have taxed the real estate at a higher rate also provide more public services to residents. Acquitted with the non-parametric distributions of our data, we employ the Spearman rank-order correlation procedure (1) 


$$
r_{s}=1-\frac{6 \sum_{i=1}^{n} d_{i}^{2}}{n^{3}-n}
$$

where $d_{i}$ is a difference between two ranks of observation and $n$ is the number of observations.

The second part of the analysis is based on the paired difference testing, i.e. comparing the initial and final periods to assess whether the samples differ. As the input data follow various non-normal distributions, to examine the presence (true/false - 1/0) of post offices and medical services we employ the McNemar test (2), suited for dichotomous data (McNemar, 1947)

$$
\chi^{2}=\frac{\left(f_{12}-f_{21}\right)^{2}}{\left(f_{12}-f_{21}\right)}
$$

where $f_{12}$ and $f_{21}$ represent positions of counts from a 2 x 2 matrix.

In addition, we apply the Wilcoxon signed-rank test used for non-normally distributed data (1945) to examine variables such as provision of educational facilities and its level (primary/secondary/false $-1 / 2 / 0$ ), size of working age population (aged 15 to 64), or size of total population. Since the test procedure is well-known but too extensive to describe, we advise consulting, for example, Zar (2010) or Sokal and Rohlf (1987) if needed, where one can find the Wilcoxon signed-rank test explained, along with the other above-mentioned methods.

\section{Results and discussion}

The analytical part is divided into two main sections. First of all, we proceed to examine any connection between the quality of life indicators and the value of local coefficients of real estate taxes. Next, we focus on dynamics of these relationships while evaluating whether the changes of local coefficients of real estate taxes were followed by changes of quality of life indicators in the individual municipalities. However, it is first necessary to identify those municipalities that have increased the local coefficient of real estate taxes. We have learned that 562 municipalities (i.e. ca 9\%) used this instrument in 2016. Figure 1 shows that these are very often located in 4 types of area: (I) the suburbs of large cities and conurbations, e.g. surrounding areas of Prague, Brno, Ostrava, Pilsen, Liberec or Budweis; (II) former heavy industrial regions with a large portion of obsolete industrial facilities, e.g. northwest and northeast parts of the Czech Republic; (III) industrial areas with large business units and infrastructure, e.g. Mladá Boleslav, Kvasiny, Dukovany or Temelín; and (IV) regions with facilities for a year-round recreation, e.g. Šumava, Krkonoše, Jeseníky or Beskydy.

Inspecting the list of municipalities which have raised the local coefficient three, four or five times, we might only guess the motivation behind their decision. On the one hand, we can find municipalities (e.g. Mladá Boleslav, Kvasiny, Nošovice, Mirošovice, Stonava, Čeladná, Boží Dar) tackling some externalities, such as infrastructure capacity expansion, noise, dustiness, air pollution, delinquency committed by precariat employed in industrial and logistical facilities in the area of municipal responsibility, influx of home waste left by non-residents. On the other hand, some municipalities do not face such local troubles at all. Nevertheless, there are vast energy power facilities in the area of municipal responsibility, for instance, atomic power station Dukovany, Temelín, or 
hydroelectric power station Lipno nad Vltavou, which do not cause any such externalities mentioned above. On the contrary, the living standard of residents may be increased by sharing the services provided by the security standards ordered by the state, e.g. fire service, police, in-house medical care, etc. This raises the question of whether the policy of rising of the local coefficient is rather immoral as some municipalities seem to have derived their policy from the ability-to-pay principle. Considering the mutual relationship between municipalities and companies conducting business in areas of their responsibilities and the EU policy of Corporate Social Responsibility (Miralles-Quiros et al., 2017), municipalities possibly should focus more on the ethics of their decision to raise the local coefficient. Based on these findings, we can assert that both positive and negative externalities brought on by a close proximity to larger municipalities, job opportunities, as well as societal cost of production, might impact decision-making related to the level of local coefficients of real estate taxes. However, we can only speculate about the weight of these factors within the comprehensive local policy-shaping process.

Figure 1 Municipalities that applied higher local coefficient of real estate taxes (2016)

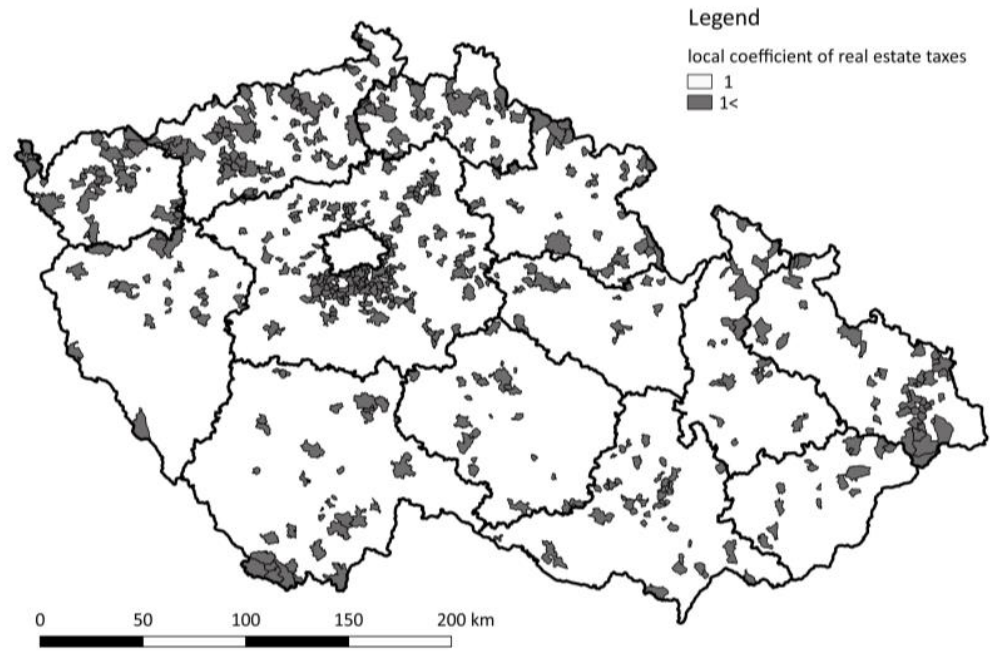

Source: Authors' own processing based on Sedmihradská and Bakoš (2017).

Focusing on all 6252 municipalities in our sample, the results shown in Table 1 suggest the level of local coefficient of real estate taxes (LCRET) correlates positively with the level of quality of life indicators. In fact, the correlation relationships are rather weak but still significant, since the coefficients are between 0.130 and 0.209 . As for the 562 municipalities that applied (i.e. increased) the instrument of local coefficient of real estate taxes, we have found all relationships to be non-significant. It is also important to note that these findings are not biased due to the sample size or the effect of critical values since the values of $r_{s}$ within all municipalities are higher. The results suggest that municipalities that are more populated and hence handle a wider supply of public services apply higher taxation of real estate. However, from the subsample of municipalities that actively use the real estate taxation instrument it is apparent that it is not true 
that the higher the coefficient of real estate taxes, the higher the quality of life, and vice versa. Based on these findings, we can suggest that the increasing of local coefficient of real estate taxes is not associated with a higher quality of life. Considering that increased taxes should be compensated also by an increase in quality of life, it does not seem justified to increase the local coefficient of real estate taxes.

Table 1. Correlation of local coefficient of real estate taxes and quality of life (2016)

\begin{tabular}{ccccccc} 
& \multicolumn{6}{c}{ all municipalities (count 6252) } \\
\cline { 2 - 7 } & Population & $\begin{array}{c}\text { WA } \\
\text { population }\end{array}$ & $\begin{array}{c}\text { Educational } \\
\text { facilities }\end{array}$ & $\begin{array}{c}\text { Medical } \\
\text { services }\end{array}$ & $\begin{array}{c}\text { Post } \\
\text { offices }\end{array}$ & $\begin{array}{c}\text { Fire } \\
\text { brigades }\end{array}$ \\
\hline LCRET & $0.208^{*}$ & $0.209^{*}$ & $0.160^{*}$ & $0.159^{*}$ & $0.130^{*}$ & $0.157^{*}$ \\
\hline
\end{tabular}

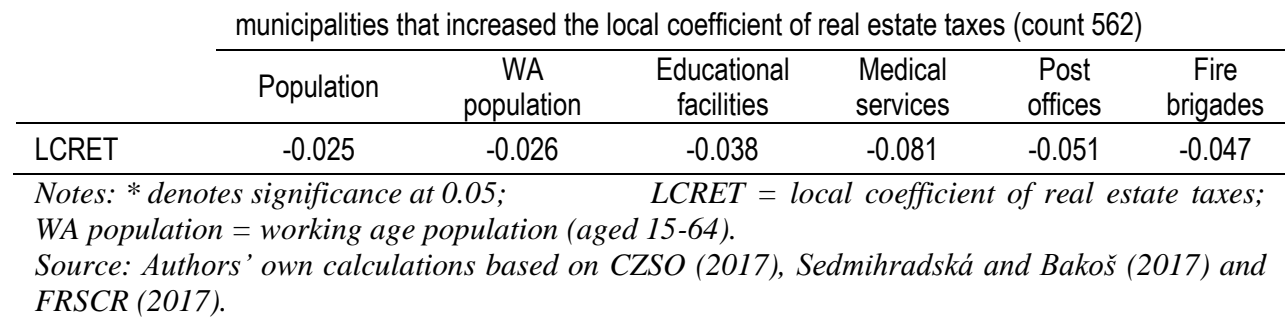

Now we approach the next part of our analysis: assessing the dynamic view on development of quality of life in municipalities that have increased the local coefficient of real estate taxes, focusing on the period 2011-2016. We should point out that only 289 municipalities (i.e. ca 5\%) applied a higher local coefficient of real estate taxes in 2016 than in 2011, while the rest 5963 did not. Table 2 demonstrates how all quality of life indicators, except for educational facilities, of municipalities that did not increase the local coefficient of real estate taxes changed significantly. In addition, the p-value of educational facilities, 0.06, is very close to our desired level of significance at 0.05 . Furthermore, the results show that only the indicators of population, working age population and educational facilities changed significantly within the sample of municipalities that increased the local coefficient of real estate taxes between 2011 and 2016.

Admittedly, these findings do not say much unless they are interpreted in terms of changes within the sample. Let us start with the indicators of population, as shown in Table 3. Since the samples are non-normally distributed, we only show the values of median, first and third quartile (Q1 and Q3), and the coefficient of variation (CV). In the sample of municipalities that did not increase the local coefficient of real estate taxes we can see that the size of total population is on the rise, while the size of working age population falls. This finding is in line with other recent researches that conclude the process of population ageing to be the general tendency both in the Czech Republic and other European countries, impacting welfare and the quality of life negatively (Feldstein, 2006; Vettori, 2016; Arltová and Langhamrová, 2010; Káčerová et al., 2012). Moreover, the variation found is very high but, more or less, stable over time. 
Table 2. Paired difference testing of local coefficient of real estate taxes and quality of life (2011-2016)

municipalities that did not increase the local coefficient of real estate taxes (5963)

\begin{tabular}{lccc} 
Indicator & $\mathrm{Z}$ & $\mathrm{p}$-value & test procedure \\
\hline Population & 16.975 & $0.000^{*}$ & Wlicoxon signed-rank \\
WA population & 26.442 & $0.000^{*}$ & Wlicoxon signed-rank \\
Educational facilities & 1.879 & 0.060 & Wlicoxon signed-rank \\
Medical services & 3.474 & $0.001^{*}$ & McNemar \\
Post offices & 4.045 & $0.000^{*}$ & McNemar
\end{tabular}

municipalities that increased the local coefficient of real estate taxes (289)

\begin{tabular}{lccc}
\cline { 2 - 4 } Indicator & $\mathrm{Z}$ & $\mathrm{p}$-value & test procedure \\
\hline Population & 5.345 & $0.000^{*}$ & Wlicoxon signed-rank \\
WA population & 3.110 & $0.002^{*}$ & Wlicoxon signed-rank \\
Educational facilities & 2.023 & $0.043^{*}$ & Wlicoxon signed-rank \\
Medical services & 0.516 & 0.606 & McNemar \\
Post offices & -0.707 & 0.480 & McNemar \\
\hline
\end{tabular}

Notes: * denotes significance at 0.05; LCRET = local coefficient of real estate taxes; WA population $=$ working age population (aged 15-64.)

Source: Authors' own calculations based on CZSO (2017), Sedmihradská and Bakoš (2017) and FRSCR (2017).

However, the results lower in Table 3 show that the tendency in municipalities that increased the local coefficient of real estate taxes is different. The figures show that the municipalities in this sample are generally bigger (with a higher market demand), while the sample variation is lower. The middle values increased while the variation slightly decreased in both population and working age population indicators. These facts could be signal a more favourable developmental pattern, as opposed to municipalities that did not increase the local coefficient of real estate taxes. This is particularly interesting as higher real estate taxation proved to result in higher costs of living. On the other hand, as mentioned above, a bigger portion of municipalities that use the instrument of real estate taxation is situated in the suburbs of large cities, in industrial and entertaining areas; so, logically, the working age population concentrates in these areas, near to job opportunities. From this it could be assumed that some municipalities enjoy the heightened inflow of working age population and construction boom regardless the level of local coefficients of real estate taxes. 
Table 3. Descriptive statistics of quality of life - population indicators (2011-2016)

\begin{tabular}{llllll} 
& \multicolumn{5}{c}{ municipalities that did not increase the local coefficient of real estate taxes (5963) } \\
\cline { 2 - 6 } Category & year & Q1 & M & Q3 & CV \\
\hline \multirow{2}{*}{ Population } & 2011 & 199 & 407 & 865 & 1179.55 \\
& 2016 & 207 & 416 & 882 & 1181.85 \\
WA & 2011 & 139 & 283 & 606 & 1188.13 \\
population & 2016 & 136 & 278 & 593 & 1185.56
\end{tabular}

\begin{tabular}{llllll} 
& \multicolumn{5}{c}{ municipalities that increased the local coefficient of real estate taxes (289) } \\
\cline { 2 - 6 } Category & year & Q1 & M & Q3 & CV \\
\hline \multirow{2}{*}{ Population } & 2011 & 413 & 862 & 2773 & 267.79 \\
& 2016 & 444 & 940 & 2778 & 264.12 \\
\multirow{2}{*}{ WA } & 2011 & 291 & 601 & 1946 & 268.28 \\
population & 2016 & 293 & 621 & 1819 & 263.74 \\
\hline
\end{tabular}

Notes: WA population $=$ working age population (aged 15-64); Q1 and Q3 = first and third quartile; $C V=$ coefficient of variation.

Source: Authors' own calculations based on CZSO (2017).

Table 4 presents the results of the quality of life indicators derived from public services like provision and the level of educational facilities, medical services, or post offices. In Table 4 we also provide two more columns with additional information about the samples - the number of municipalities with their services under examination which refer to a "sample breakpoint" between the presence and absence of a particular quality of life indicator; and the percentage change between 2011 and 2016. This allows us to compare the development of samples of unequal sizes. The table clearly demonstrates that the level of public services is higher in those municipalities that increased the local coefficient of real estate taxes. This result from the fact that the majority of municipalities that increased the local coefficient of real estate taxes provides educational facilities, medical services and post offices to their citizens, while in the other municipalities the absence of these services prevails. These results are not surprising since the larger sample involves a high number of very small municipalities with a limited demand and hence a smaller need for such services. However, there are other, more vivid differences between both samples, especially in terms of development.

Focusing on development, the analysis proved that the number of municipalities that provide educational facilities, medical services and post offices slightly decreased between 2011 and 2016 in the sample of municipalities that did not increase the local coefficient of real estate taxes. It should be pointed out here that the previous testing procedures only identified these decreases to be significant for indicators of medical services and post offices. In contrast, the results for the other sample show that the counts slightly increased or remained the same within the period of 2011-2016, and the analysis only found only the change of the educational facilities indicator to be significant. In fact, the total difference in the number of educational facilities over the period (i.e. 5) is very low. The Wilcoxon signed-rank testing procedure result is not wrong as 
we have identified more than five changes within the sample; but these changes are not so obvious from a simple comparison of aggregated numbers presented in the table. In addition, one can see the variation is lower and slightly decreasing over time within the sample of the municipalities that increased the local coefficient of real estate taxes.

Table 4. Descriptive statistics of quality of life - public services indicators (2011-2016)

\begin{tabular}{lccccccc} 
& \multicolumn{6}{c}{ municipalities that did not increase the local coefficient of real estate taxes (5963) } \\
\cline { 2 - 8 } Category & year & Count & Change & Q1 & Median & Q3 & CV \\
\hline Educational & 2011 & $2386(1203)$ & & 0 & 0 & 1 & 133.25 \\
facilities & 2016 & $2377(1196)$ & $-0.4 \%$ & 0 & 0 & 1 & 133.66 \\
Medical & 2011 & 2045 & & 0 & 0 & 1 & 138.43 \\
services & 2016 & 1979 & $-3.2 \%$ & 0 & 0 & 1 & 141.90 \\
Post & 2011 & 2473 & & 0 & 0 & 1 & 118.81 \\
offices & 2016 & 2442 & $-1.3 \%$ & 0 & 0 & 1 & 120.09
\end{tabular}

\begin{tabular}{lccccccc} 
& \multicolumn{7}{c}{ municipalities that increased the local coefficient of real estate taxes (289) } \\
\cline { 2 - 7 } Category & year & Count & Change & Q1 & Median & Q3 & CV \\
\hline Educational & 2011 & $173(120)$ & & 0 & 1 & 2 & 89.28 \\
facilities & 2016 & $178(120)$ & $+2.9 \%$ & 0 & 1 & 2 & 86.80 \\
Medical & 2011 & 164 & & 0 & 1 & 1 & 87.46 \\
services & 2016 & 167 & $+1.8 \%$ & 0 & 1 & 1 & 85.62 \\
Post & 2011 & 174 & & 0 & 1 & 1 & 81.44 \\
offices & 2016 & 174 & $+0.0 \%$ & 0 & 1 & 1 & 81.44
\end{tabular}

Notes: The count refers to the number of municipalities with a particular service; $Q 1$ and Q3 = first and third quartile; $C V=$ coefficient of variation. Brackets denote how many of the municipalities have a secondary level of educational facilities.

Source: Author' own calculations based on CZSO (2017).

\section{Conclusion}

Since the 1990s, the Czech intergovernmental fiscal relations have been undergoing a transformation. It is seen as a part of an economic transition focusing on the abandonment of centralism and the shift to pluralism. Any fiscal decentralization has been hence viewed as a principal component of democratic development so far. As the spin-off of the fiscal stress implied by the financial crisis of 2007-2008 can be considered the strengthening of the autonomy of local authorities by empowering them to change the real estate tax rate. Since 1 January 2009, they were able to use the instrument of the local coefficient. By adjusting it from 1 up to 5, municipalities were able to maximize their revenues from real estate tax.

We have carried out an analysis to scrutinize the interrelationship between the level of property taxation and quality of live in the Czech municipalities, and some important conclusions could be drawn from it. We have found that there are some differences between the municipalities that increased the local coefficient of real estate taxes and 
those that did not. In the second case, the municipalities are more threatened by population ageing since they face growing size of total population, while the size of working age population is declining. Furthermore, the provision of public services in these municipalities is slightly declining as well. Whereas the municipalities that did increase the coefficient of real estate taxes experienced an increase in both population and working age population sizes. Moreover, these municipalities do not face the problem of shrinking of public services. In general, the increased amount of taxes seems to be used reasonably and justifiably by local governments as attractiveness for working age population and stability in the supply of public services indicate a solid potential for further development. Also, the policy of raising local coefficient implies a potential for ongoing development of districts.

Admittedly, our generalized conclusions are rather limited as the results of the analysis may, to some extent, be biased. There are various reasons for that. We have already mentioned the factor of the availability of job opportunities that may influence the development patterns regardless the local government's actions. Another reason is that other data like the quality and spatial proximity of services and not just their availability, as well as differences in purchasing power of inhabitants, general political directions and priorities, or path-dependence all impact the developmental patterns, but we were unable to access and use them. Finally, due to the unavailability of data for the bottom level of regional hierarchy there are many other important factors of quality of life that could not be included in this analysis, e. g. environmental, societal, public order, etc.

The national issue of increasing the municipal incomes by policy of rising of the local coefficient, which we paid a closer attention to in the article, needs to be considered in a broader linkage with demographic paradigm change. This is opening a next door for further research - and not only from the point of view of public finance or theories of local development. For instance, it could be analysed whether the upcoming population aging and ongoing rural depopulation should be tackled by raising of the local coefficient (an individual action at the local level of the state organization) or by periodic reframing of the distribution of tax yield (a collective action at the central level of the state organization); what ethical aspects such policies have; how moral the policy of raising of the local coefficient is in the environment of local players; or how much this policy is redistributive.

Disclosure statement: No potential conflict of interest was reported by the authors.

\section{References}

ALM, J. (2013). A Convenient Truth: Property Taxes and Revenue Stability. Cityscape, $15(1), 243-245$.

ARLTOVÁ, M., LANGHAMROVÁ, J. (2010). Migration and ageing of the population of the Czech Republic and the EU countries. Prague Economic Papers, 1, 54-73.

AVELlANEDA, C., N. (2009). Mayoral Quality and Local Public Finance. Public Administration Review, 69(3), 469-486. DOI: 10.1111/j.1540-6210.2009.01993.X 
BEČICA, J. (2014). Czech Municipalities and Real Estate Tax. In. Sedmihradska, L. Proceedings of the 19th International Conference: Theoretical and Practical Aspects of Public Finance. Prague.

BLOM-HANSEN, J., MONKERUD, L., CH., SORENSEN, R. (2006). Do parties matter for local revenue policies? A comparison of Denmark and Norway. European Journal of Political Research 45(3), 445-465. DOI: 10.1111/j.1475-6765.2006.00305.x

CHERNICK, H., LANGLEY, A., RESCHOVSKY, A. (2011). The impact of the Great Recession and the housing crisis on the financing of America's largest cities. Regional Science and Urban Economics, 41(4), 372-381. DOI: 10.1016/j.regsciurbeco.2011.04.002

CROWLEY, G., L., SOBEL, R., S. (2011). Does fiscal decentralization constrain Leviathan? New evidence from local property tax competition. Public Choice, 149, 5-30. DOI: $10.1007 / \mathrm{s} 11127-011-9826-7$

CZSO - CZECH STATISTICAL OFFICE (2017). Public database. [accessed 05-202017] https://vdb.czso.cz/vdbvo2/.

DOYAL, L., GOUGH, I. (1991). A Theory of Human Need. Basingstoke: Macmillan.

FELDSTEIN, M. (2006). The Effects of the Ageing European Population on Economic Growth and Budgets: Implications for Immigration and Other Policies. NBER Working Paper Series, No. 12736.

FISHER, W., G., FAIRBANKS, R., B. (1967). The Politics of Property Taxation. Administrative Science Quarterly, 12(1), 48-71. DOI: 10.2307/2391212

FRSCR - FIRE RESCUE SERVICE OF THE CZECH REPUBLIC. (2017). Internal databases.

KÁČEROVÁ, M., ONDAČKOVÁ, J., MLÁDEK, J. (2012). A comparison of population ageing in the Czech Republic and the Slovak Republic based on generation support and exchange. Moravian Geographical Reports, 20, 26-38.

KOROVCHENKO, T. (2016). Measuring quality of life in EU capitals. 10th Anniversary International Conference INPROFORUM 2016. České Budějovice: University of South Bohemia, 33-38.

LUTZ, B., MOLLOY, R., SHAN, H. (2011). The housing crisis and state and local government tax revenue: Five channels. Regional Science and Urban Economics 41(4) 306-319. DOI: 10.1016/j.regsciurbeco.2011.03.009

MCNEMAR, Q. (1947). Note on the sampling error of the difference between correlated proportions or percentages. Psychometrika, 12(2), 153-157. DOI: $\underline{10.1007 / \mathrm{BF} 02295996}$

MIRALLES-QUIROS, M., MIRALLES-QUIROS, J., L., ARRAIANO, I., G. (2017) Are Firms that Contribute to Sustainable Development Valued by Investors? Corporate Social Responsibility and Environmental Management 24(1), 71-84. DOI: $\underline{10.1002 / \mathrm{csr} .1392}$ 
NOLL, H. (2002). Towards a European system of social indicators: theoretical framework and system architecture. Social Indicators Research, 58, 47-87. DOI: 10.1023/A:1015775631413

PHILlIPS, D. (2006). Quality of Life: Concept, Policy and Practice. London: Routledge.

QUIZILBASH, M. (1998). The concept of well-being. Economics and Philosophy, 14, 51-74. DOI: $10.1017 / \mathrm{S} 0266267100004934$

PIKE, A., RÓDRIGUEZ-POSE, A., TOMANEY, J. (2006). Local and Regional Development. London: Routledge.

ROGERSON, R, FINDLAY A., PADDISON, R., MORRIS, A. (1996). Class, consumption and quality of life. Progress in planning, 45, 1-66. DOI: 10.1016/03059006(95)00005-4

SCHNEIDER, M. (1987). Local Budgets and the Maximization of Local Property Wealth in the System of Suburban Government. The Journal of Politics, 49(4), 11041116. DOI: $\underline{10.2307 / 2130787}$

SEDMIHRADSKÁ, L., BAKOŠ, E. (2015). Who Applies the Real Estate Tax`s Local Coefficient? Prague: Oeconomica.

SEDMIHRADSKÁ, L., BAKOŠ, E. (2016). Municipal Tax Autonomy and Tax Mimicking in Czech Municipalities. Lex Localis - Journal of Local Self-Government. 14(1), $75-92$.

SEDMIHRADSKÁ, L., BAKOŠ, E. (2017). Property tax local coefficient/Místní koeficient $u$ daně $z$ nemovitých věcí (2009-2017). [accessed 05-25-2017] https://www.researchgate.net/publication/314658534_Property_tax_local_coefficientMi stni_koeficient_u_dane_z_nemovitych_veci_2009-2017.

SEDMIHRADSKÁ, L. (2013). Yardstick Competition in Case of the Czech Property Tax. Review of Economic Perspectives, 13(2), 77-91. DOI: 10.2478/revecp-2013-0002

SKIDMORE, M., SCORSONE, E. (2011). Causes and consequences of fiscal stress in Michigan cities. Regional Science and Urban Economics 41(4), 360-371. DOI: 10.1016/j.regsciurbeco.2011.02.007

SMITH, S., M., BRYSON, P.J., CORNIA, G.C. (2011). The view from city hall: Local perceptions of intergovernmental fiscal relations in the Czech Republic. Communist and Post-Communist Studies 44(1), 99-110. DOI: 10.1016/j.postcomstud.2011.01.009

SOKAL, R., ROHLF, J. (1987). Introduction to Biostatistics. New York: Dover Publications.

STEVENS, J.B., MASON, R. (1996). Political markets, property tax referenda, and local school spending. Public Choice. 86, 257-277.

VETTORI, S. (2016). Ageing Populations and Changing Labour Markets. Boca Raton: CRC Press.

WILCOXON, F. (1945). Individual comparisons by ranking methods. Biometrics Bulletin, 1(6), 80-83. 
REVIEW OF ECONOMIC PERSPECTIVES

ZAR, J. (2010). Biostatistical Analysis. London: Prentice Hall. 